\title{
The Implementation of Regional Civil Servant Investigator in Law Enforcement in Kuningan District, Indonesia
}

\author{
Ade Suhendra, Haris Budiman and Erga Yuhandra \\ Faculty of Law, Universitas Kuningan. 45513, Indonesia. \\ E-mail: adesuhendra1979@gmail.com
}
How to cite : Ade Suhendra, Haris Budiman and Erga Yuhandra. (2019). The Implementation of Regional Civil Servent Investigator in Law Enforcment in Kuningan District, Indonesia. UNIFIKASI : Jurnal IImu Hukum, 6(1), 23-33. DOI : 10.25134/unifikasi.v6i1.875
Submitted : 28-03-2018 Revised : 31-05-2019 Accepted : 10-06-2019

\begin{abstract}
This research aims to analyze the regulation of Civil Servant Investigator based on Regional Regulation No. 6 of 2005 and the implementation of Regional Regulation No. 6 of 2005 concerning Regional Civil Servant Investigator at Office of Kuningan District Civil Service Police Unit. This descriptive-analytical research applied a normative juridical approach. The results showed that based on Regional Regulation No. 6 of 2005, Regional Civil Servant Investigator has the duties of conducting investigation on violations of Regional Regulations in which each Regional Civil Servant Investigator must be equipped with an investigation warrant signed by the supervisor of the Regional Civil Servant Investigator in conducting the investigation. Besides, Regional Civil Servant Investigator also has the duties of providing coaching which includes general, technical, and operational coaching for Civil Servant Investigator. Further, regarding the implementation of Regional Regulation No. 6 of 2005 concerning Regional Civil Servant Investigator at Office of Kuningan District Civil Service Police Unit, the Regional Civil Servant Investigator generally has carried out its duties in conducting investigation and inspection towards illegal buildings, places of business and business activities; conducting investigation and inspection towards community, apparatus or legal entities violating regional regulations, head district regulations, and head district decisions; and preparing material to be submitted to the National Police regarding follow up actions towards community, apparatus or legal entities violating regional regulations, head district regulations, and head district decisions. Thus, it can be concluded that, in general, Regional Regulation No. 6 of 2005 concerning Regional Civil Servant Investigator at Office of Kuningan District Civil Service Police Unit has been implemented well.
\end{abstract}

Keywords: Implementation; Civil Servant Investigator; Civil Service Police Unit

\section{Implementasi Penyidik Pegawai Negeri Sipil Daerah dalam Penegakan Hukum di Kuningan, Indonesia}

\begin{abstract}
Abstrak : Pancasila adalah hasil konsensus bersama para pendiri bangsa Indonesia. Pancasila sebagai ideologi dan pandangan hidup bangsa memberikan arah dan tujuan untuk membangun masyarakat Indonesia yang adil dan makmur dalam NKRI. Tujuan penelitian ini adalah bagaimana Aksiologi Pancasila dalam Rekonstruksi Budaya Hukum Di Indonesia. Metode penelitian yang digunakan dalam penelitian ini adalah yuridis normatif. Hasil penelitian yaitu Pancasila tercantum dalam Pembukaan UUD 1945 sebagai konsitusi Negara yang perlu diaktualisasikan dalam kehidupan sehari-hari. Sehingga memberikan konsekuensi, bahwa nilai-nilai Pancasila sebagai hasil kristalisasi budaya bangsa yang bersifat multikulturalisme harus tercermin dalam pola pikir, cipta rasa dan tingkah laku masyarakat Indonesia. Dalam bidang hukum, nilai-nilai Pancasila harus tercermin dalam penegakan hukum yang berwatak rasa keadilan sosial bagi seluruh rakyat Indonesia. Sehingga budaya hukum yang berkarakter nilai-nilai Pancasila perlu diaktualisasikan demi terwujudya kesadaran hukum nasional dalam upaya membangun hukum yang mengayomi dan memberikan rasa keadilan bagi seluruh rakyat Indonesia.

Kata Kunci: Nilai Pancasila, Nilai, dan Budaya Hukum
\end{abstract}

\section{INTRODUCTION}

The ideals as well as the national goals of the Indonesian Nation are clearly stated at the Preamble of the 1945 Constitution of the Republic of Indonesia. The national goals of the Indonesian nation are to protect the whole people of Indonesia and the entire homeland of Indonesia, to advance general prosperity, to develop the nation's intellectual life, and to contribute to the implementation of a world order based on freedom, lasting peace and social justice. To achieve these national goals, a sustainable 
development, which is a series of comprehensive and integrated development including development in the field of law and government apparatus, is carried out by the government. ${ }^{1}$

Governance is an element or component that plays a significant role in establishing a good state. Good governance can be realized if there is a transparent, participatory, accountable and democratic synergy between private sectors, community and government as a facilitator. The process of realizing good governance requires 'tools' in implementing government policies and regulations. One of the 'tools' to realize good governance is government apparatus, in this case, Civil Servant (PNS). ${ }^{2}$

Law No. 43 of 1999 concerning The Ordinance of the Civil Service describes that A Civil Servant (PNS) is each and every citizen of the Republic of Indonesia who has met the stipulated requirements and who has been appointed by an authorized official and who is charged to take a civil service position or who is charged with other to tasks by the state and who is paid a salary pursuant to the legislation in force. In addition, Article 3 Paragraph (1) of Law No. 43 of 1999 states that a civil servant has the status of being a constituent of the state apparatus who is charged with providing services to the public in a professional, honest, just and equitable manner in the context of discharging state, government and development tasks. Further, Article 4 of Law No. 43 of 1999 notes that each and every civil servant shall adhere to and be loyal to Pancasila, 1945 Constitution, the state and government and he or she shall safeguard the unity and unification of the nation in the unitary state of the Republic of Indonesia. Civil servants have a crucial role in enforcing legislations so that the Civil Servant Investigator (PPNS) is formed.

PPNS is a civil servant who is appointed and given the authority to conduct investigation in certain criminal acts belonging to certain legislations that become their basis. Therefore, each government agency or institution has its own PPNS. In carrying out its duties, PPNS are monitored by Police Investigator. In Law No. 32 of 2004 concerning Regional Administration as amended by Article 149 of Law No. 9 of 2015, it is explained that PPNS has a role as enforcer of Regional Regulations (Perda). Besides being regulated in sectoral laws, the existence and function of PPNS are also recognized in Article 6 of Law No. 8 of 1981 concerning The Law of Criminal Procedure (HAP), Article 14 of Law No. 2 of 2002 concerning National Police of the Republic of Indonesia, Government Regulation No. 27 of 1983 concerning the Implementation of Criminal Code, and Regulation of the Minister of Home Affairs No. 4 of 1997 concerning Civil Servant Investigator. Based on the provision of Article 6 paragraph (1) letter b of Law No. 8 of 1981, PPNS is a certain official of the civil service who is granted special authority by law. The special authority refers to the investigation authority in accordance with the Law which becomes the legal basis in carrying out its duties. It should be noted that the functions, duties and authorities of investigations are actually inherent in the officials of National Police of the Republic of Indonesia. Meanwhile, PPNS is a civil servant who is given special task and authority to conduct investigation in accordance with the Law which becomes the legal basis in carrying out its duties. Functionally, the appointment of PPNS is intended specifically to conduct investigations in certain fields in accordance with the Law which becomes the legal basis in carrying out its duties.

The investigation carried out by PPNS in Kuningan District is regulated in Kuningan District Regulation No. 6 of 2005 concerning Regional Civil Servant Investigator. This Regional Regulation notes that Regional Civil Servant Investigator, hereinafter referred to as Regional PPNS, is a civil servant within the regional government who is granted special authority by Law to conduct investigation. Investigation is a series of investigative actions in terms of and in the manner stipulated in

\footnotetext{
1 Intan A. Ramadini, Kinerja Penyidik Pegawai Negeri Sipil (PPNS) Kota Tangerang, Skripsi, FISIP Universitas Sultan Ageng Tirtayasa Serang, 2015, p. 1.

2 Ibid.
} 
Law No. 8 of 1981 to search for and collect evidence that can be used to uncover a criminal act in order to find the suspect.

Civil Service Police Unit (Satpol PP) is one of government agencies located in Kuningan District. According to Government Regulation of the Republic of Indonesia No. 6 of 2010 concerning Civil Service Police Unit, Civil Service Police Unit is part of regional apparatus in enforcing regional regulations and realizing public order and peace. Civil Service Police is a member of Civil Service Police Unit as a regional government apparatus in enforcing regional regulations and realizing public order and peace. With the tasks stipulated in Government Regulation, Kuningan District Civil Service Police Unit is required to have competent and skilled Civil Service Police personnel. In carrying out its duties, Civil Service Police Unit as a state apparatus must be professional, responsible, honest and just. The existence of PPNS, which has a special task and authority to conduct investigations on violations of regional regulations, is expected to create public order and peace, especially in Kuningan District. Based on the background previously described, the problems discussed in this research are formulated into the following questions: 1). How is the regulation of Civil Servant Investigator (PPNS) based on Regional Regulation No. 6 of 2005? and 2). How is the implementation of Regional Regulation No. 6 of 2005 concerning Regional PPNS at Office of Kuningan District Civil Service Police Unit?

\section{RESEARCH METHODS}

This descriptive-analytical research applied an empirical juridical approach. The data in the form of primary and secondary legal materials were collected through literature and field study. The collected data were then analyzed by using descriptive analysis method. In addition, this research also analyzed the legislations and other documents relating to the problem under study ${ }^{3}$.

\section{RESULTS AND DISCUSSION}

\section{The Regulation of Civil Servant Investigator (PPNS) Based on Regional Regulation No. 6 of 2005}

Article 1 Paragraph (3) of the 1945 Constitution of the Republic of Indonesia describes that the State of Indonesia is a state based on the rule of law. The rule of law is a country in which its governance is run based on a legal basis rooted in a set of normative starting points in the form of basic principles serving as a guideline and criteria for evaluating governance and government officials' behavior. $^{4}$

Law enforcement is a process which is initially the application of directors involved in making decisions that are not strictly governed by the rule of law but has element of personal judgment. Conceptually, the essence and meaning of law enforcement lies in the activity of harmonizing the relationships of values outlined in solid principles and attitude as a series of interpretation of the final stage values to create, realize, and maintain social order. ${ }^{5}$ Law No. 9 of 2015 concerning Regional Government defines an autonomous region as a legal community unit that has territorial boundaries and is authorized to regulate and manage government affairs and interests of the local community based on their own initiatives as well as community's aspirations in the Unitary State of the Republic of Indonesia. Welfare approach is an approach that must be continuously applied both through bureaucratic reform and community services improvement. ${ }^{6}$

\footnotetext{
${ }^{3}$ Ibid., p.93

4 Rocky Marbun dkk, Kamus Hukum Lengkap: Mencakup Istilah Hukum dan Perundang-Undangan Terbaru, Visimedia, Jakarta, 2012, p. 78.

5 Soerjono Soekanto, Faktor-faktor yang Mempengaruhi Penegakan Hukum, PT. Raja Grafindo Persada, Jakarta, 2012, p. 5.

${ }^{6}$ Haris Budiman dan Suwari Akhmaddhian, "Implementasi Reformasi Birokrasi Bidang Perizinan Pananaman Modal di Kabupaten Kuningan” Jurnal Unifikasi, ISSN 2354-5976 Vol. 1 No. 1 Oktober 2013.1-19.
} 
In line with Law No. 9 of 2015 concerning Regional Government, the governance in District and City is based on the principle of decentralization. By applying the principle of decentralization in districts and cities, both districts and cities have become fully autonomous regions ${ }^{7}$. Thus, regional autonomy is the authority granted by the central government to the regions, both districts and cities, to regulate, manage, control and develop their own affairs in accordance with the capabilities of their regions and refer to the legislations in force.

As an effort to enforce regional regulations in Kuningan District, Civil Servant Investigator (PPNS) which is regulated in Regional Regulation No. 6 of 2005 concerning Regional PPNS was formed. The regulation describes general provisions; position; duties, authorities, rights and obligations; appointment, transfer and dismissal; oath/promise and inauguration; ID cards; ways of conducting investigations; coaching; as well as financing of Regional Civil Servant Investigator in Kuningan District as stipulated in Article 1 - Article 24 of Regional Regulation No. 6 of 2005. Article 1 of Regional Regulation No. 6 of 2005 describes that an investigator is an official of the National Police of the Republic of Indonesia or a certain official of Civil Servants who is granted special authority by law to conduct investigations. Regional Civil Servant Investigator, hereinafter abbreviated as Regional PPNS, is a certain civil servant in Regional Government who is granted special authority by law to conduct investigations. Meanwhile, investigation itself is a series of investigative actions in terms of and in the manner stipulated in Law No. 8 of 1981 to search for and collect evidence that can be used to uncover a criminal act in order to find the suspect.

Article 2 of Regional Regulation No. 6 of 2005 explains that Regional PPNS is under the leadership of and responsible to the District Head. Further, based on Article 3 of Regional Regulation No. 6 of 2005, Regional PPNS has the duties of conducting investigation on violations of Regional Regulations. In carrying out its duties, Regional PPNS are monitored by Indonesian Police Investigator. Article 4 of Regional Regulation No. 6 of 2005 states in carrying out its duties, Regional PPNS has the following authorities:

a. Accommodating any reports or complaints regarding a criminal act in violation of a Regional Regulation;

b. Performing a preliminary action and inspection at the scene;

c. Asking someone to stop and checking his identity;

d. Confiscating object or letter;

e. Taking someone's fingerprints and pictures;

f. Calling people to be examined as a suspect or witness;

g. Inviting experts in relation to the examination of a case;

h. Stopping investigation after receiving instruction from the investigator because there is not enough evidence or the action is not a criminal act. Then, informing it to the public prosecutor and the suspect/his family;

i. Carrying out other actions based on law.

Based on Article 5 of Regional Regulation No. 6 of 2005, Regional PPNS can be given incentives in addition to obtaining its right as a civil servant as stated in Law No. 43 of 1999. The amount of incentive is further determined by the District Head by taking into account the conditions and financial capabilities of the region. According to Article 6 of Regional Regulation No. 6 of 2005, Regional PPNS has obligations to:

a. Investigate a criminal act which is suspected violating a certain regional regulation;

b. Submit the investigation results to the Public Prosecutor through the National Police Investigator in the regional jurisdiction;

7 Hanif Nurcholis, Teori dan Praktik Pemerintahan dan Otonomi Daerah, Grasindo, Jakarta, 2007, hlm. 29. 
c. Make a criminal report of each action taken relating to examination of suspects, confiscation of goods, examination of witnesses, and inspection of scene;

d. Make a task implementation report to be submitted to the District Head through the Head of Work Unit.

Article 7 of Regional Regulation No. 6 of 2005 describes that the appointment of Regional PPNS is the authority of the Minister of Law and Human Rights after receiving recommendation from the Attorney General and the National Police. Meanwhile, the appointment of Regional PPNS is proposed by the District Head to the Minister of Law and Human Rights through the Minister of Home Affairs, in this case the Secretary General of the Minister of Home Affairs with a copy to the Governor. Further, Article 8 of Regional Regulation No. 6 of 2005 notes that a Civil Servant who will be appointed as Regional PPNS shall meet the following criteria:

a. Rank as low as First Class Junior Supervisor/Pengatur Muda Tingkat I (II/b);

b. Education as low as Bachelor's Degree (D3);

c. Assigned in the field of operational technical;

d. Has passed a special education in the field of investigation;

e. Work Implementation Assessment Checklist (DP.3) has a good average score for 2 (two) consecutive years;

f. Physically and mentally healthy proven by a doctor's statement.

Further, Article 9 of Regional Regulation No. 6 of 2005 declares that the appointment proposal of Regional PPNS must attach the following documents:

a. Photocopy of Regional Regulation which becomes the legal basis for granting authority as the proposed PPNS;

b. Certificate of working area of the proposed PPNS;

c. Legalized photocopy of the last diploma;

d. Legalized photocopy of the latest Decree on Appointment/Rank;

e. Legalized photocopy of Work Implementation Assessment Checklist (DP.3) for 2 (two) consecutive years;

f. Legalized photocopy of Certificate of Special Education and Training (STTPP) in the field of investigation;

g. Doctor's statement stating that the related Civil Servant is in a good health.

Article 10 of Regional Regulation No. 6 of 2005 states that the transfer of Regional PPNS is carried out by the District Head and is reported to the Minister of Home Affairs through the Secretary General of the Minister of Home Affairs with a copy to the Minister of Law and Human Rights. Further, Article 11 of Regional Regulation No. 6 of 2005 explains that Regional PPNS is dismissed from his positions due to several factors, including stopping as a Civil Servant at his own request, violating staffing discipline, no longer fulfilling the requirements as a Regional PPNS, and passed away. Based on Articles 12 and 13 of Regional Regulation No. 6 of 2005, the dismissal of Regional PPNS is proposed by the District Head to the Minister of Law and Human Rights through the Minister of Home Affairs, in this case the Secretary General of the Minister of Home Affairs with a copy to the Governor. The dismissal proposal of Regional PPNS must be accompanied by clear reasons and supporting evidence. The dismissal of Regional PPNS is the authority of the Minister of Law and Human Rights.

Based on Article 14, 15, 16, 17, and 18 of Regional Regulation No. 6 of 2005, Regional PPNS must take an oath/promise before the inauguration. The inauguration of Regional PPNS is carried out by the District Head or the appointed official. The procedure of inauguration and oath/promise of Regional PPNS consists of; reading of the Decree on PPNS Appointment, pronouncing oath/promise in front of witnesses, signing letter of oath/promise and inauguration, and inauguration. The form and contents of the letter of oath/promise and inauguration of Regional PPNS are further regulated by District Head Decision. The inauguration of Regional PPNS must be in accordance with the applicable protocol in the 
Regional Government. Meanwhile, the place of inauguration and oath/promise of Regional PPNS is determined by the District Head. Regional PPNS identification card is regulated by Regional Regulation No. 6 of 2005 that each Regional PPNS must have an identification card. The ID card is signed by the District Head and can be delegated to regional secretary or head of legal department. This ID card is valid for five years starting from the date of issueance. Meanwhile, the form and contents of identification card is further regulated by the District Head. Article 19 of Regional Regulation No. 6 of 2005 states each Regional PPNS must be equipped with an investigation warrant signed by the Regional PPNS supervisor in carrying out its investigative duties.

Further, Article 20, 21, 22, and 23 of Regional Regulation No. 6 of 2005 declares that coaching for PPNS includes general, technical, and operational coaching. General coaching is the responsibility of the Minister of Home Affairs which is done in the form of providing guideline, training, and supervising relating to the empowerment of Regional PPNS. Technical coaching is the responsibility of the Minister of Law and Human Rights, the Chief of the Indonesian National Police and the Attorney General in accordance with their duties and functions. Meanwhile, operational coaching is carried out by the District Head in cooperation with relevant agencies in the form of operational guidelines for Regional PPNS. In conducting this coaching, the District Head can form a Regional PPNS Advisory Team. The operational guidelines for Regional PPNS and the formation of a Regional PPNS Advisory Team are further regulated by District Head Regulations. Meanwhile, the financing of Regional PPNS is regulated in Article 24 of Regional Regulation No. 6 of 2005 in which it is stated that all costs related to the implementation of coaching come from APBN and all costs related to the implementation of operational coaching come from APBD.

\section{The Implementation of Regional Regulation No. 6 of 2005 concerning Regional PPNS at Office of Kuningan District Civil Service Police Unit}

Theoretically, the term legislation has two meanings. Firstly, legislation is defined as a process of formulating state regulations both at the central and regional levels. Secondly, legislation is defined as all state regulations which are the result of the formulation of regulations both at the central and regional levels. ${ }^{8}$ The formulation of legislation is basically one part of the formulation of written law because the formation of written law is not only in the form of legislation but also includes the formation of treaties and jurisprudence. ${ }^{9}$

Regional regulations containing criminal law rules have rapidly developed. Basically, this development is intended to create order in local community. Historically, regional regulation as local law has been existed since the days of the Dutch East Indies in the form of customary criminal law and written criminal law established by local governments to regulate legal interests arising from local communities. Regional autonomy regulated in Law No. 9 of 2015 concerning Regional Government gives freedom to each autonomous region to regulate and manage their own government affairs based on the principle of autonomy. As an autonomous region, the provincial, district and municipal governments are authorized to develop regional regulation and regional head regulation in order to carry out regional autonomy affairs. Regional regulation is established by regional head after receiving approval from the Regional Representatives Council. The substance or content of regional regulation is an elaboration of the higher level legislation by taking into account the characteristics of each region. The material substance must not conflict with public interest and higher legislations. A regional regulation has a jurisdiction right after being enacted in a Decree. Yet, the development of regional regulations shall be based on the principle of legislation development.

8 Ridwan H. R., Hukum Administrasi Negara, UII Press, Yogyakarta, 2012, p. 99.

9 Widodo Ekatjahjana, Pembentukan Peraturan Perundang-Undangan Dasar-Dasar dan Teknik Penyusunannya, Citra Aditya Bakti, Bandung, 2008, p. 5. 
Civil service police unit is responsible of carrying out physical tasks in the form of controlling the implementation of regional regulation in the field as well as carrying out its duties and functions as coach, instructor and motivator for the community to be able to actively participate and be responsible voluntarily and continuously to always obey the regional regulation in force as a whole.

The scope of functions and duties of civil service police in realizing public order and peace is basically quite broad. Thus, civil service police unit is required to prepare both in terms of the number and the quality of personnel. The civil service police unit as an institution in the civil administration must be able to increase active participation of the community in realizing and maintaining peace and order so as to create a more conducive climate in the region. The presence of civil service police in regional administration has a strategic role because its duties are to assist regional head in realizing peace and order as well as to enforce regional regulations so that it can have an impact on efforts to increase local own-source revenue. Therefore, as stipulated in the provisions of Article 6 of Government Regulation No. 6 of 2010 concerning Civil Service Police Unit, civil service police unit has the authorities to:

a. Conduct non-judicial control against community members, apparatus or legal entities that violate regional regulations and/or regional head regulations.

b. Take action against community members, apparatus or legal entities that disturb public order;

c. Facilitate and empower community protection capacity;

d. Conduct investigative actions against community members, apparatus or legal entities suspected of violating regional regulations and/or regional head regulations; and

e. Conduct administrative actions against community members, apparatus or legal entities that violate regional regulations and/or regional head regulations.

The imposition of criminal sanction contained in regional regulation leads to the idea of forming civil servant investigator in regional government. Civil service police unit as part of regional apparatus has the duties in enforcing regional regulations as well as realizing public order and peace. Civil service police who meet the criteria can be appointed to be civil servant investigator in accordance with legislations in force.

The appointment of civil servant investigator as an institution that is responsible to conduct investigation in certain violation of regional regulation, other than police officers, is based on the provisions of Article 6 of the Code of Criminal Procedure and Government Regulation No. 58 of 2010 concerning Amendments to Government Regulation No. 27 of 1983 concerning the Implementation of the Code of Criminal Procedure. The existence of civil servant investigator in enforcing regional regulations is intended to help police investigators as well as to make civil servant investigator be more professional considering that most of the substances stipulated in regional regulations are related to regional government policies. As explained by Head of Investigation Section of Kuningan District Civil Service Police Unit, in general, the implementation of Regional Regulation No. 6 of 2005 concerning Regional PPNS at Office of Kuningan District Civil Service Police Unit has been carried out well since it is in accordance with the established provisions and procedures. ${ }^{10}$

Each month, Regional PPNS at Office of Kuningan District Civil Service Police Unit has carried out its task of investigating violation of Regional Regulations in accordance with its work programs and reports received from the community. The authorities of Regional PPNS at Office of Kuningan District Civil Service Police Unit that are frequently implemented include; accommodating any reports or complaints regarding a criminal act in violation of a Regional Regulation; performing a preliminary action and inspection at the scene; asking someone to stop and checking his identity; confiscating object or letter; taking someone's pictures; and carrying out other actions based on law. In general, Regional

10 Interview Result with Mr. Eman Sulaeman, S.Sos as Head of Investigation of Kuningan District Civil Service Police Unit on 30 May 2017. 
PPNS at Office of Kuningan District Civil Service Police Unit have carried out its duties of conducting investigation and inspection towards illegal buildings, places of business and business activities; conducting investigation and inspection towards community, apparatus or legal entities violating regional regulations, head district regulations, and head district decisions; and preparing material to be submitted to the National Police regarding follow up actions towards community, apparatus or legal entities violating regional regulations, head district regulations, and head district decisions.

Regional PPNS at Office of Kuningan District Civil Service Police Unit has received its rights in the form of monthly incentive based on the established provisions. In terms of its obligations, Regional PPNS at Office of Kuningan District Civil Service Police Unit has conducted an investigation in a criminal act which is suspected violating a certain regional regulation; submitted the investigation results to the Public Prosecutor through the National Police Investigator in the regional jurisdiction; make a criminal report of each action taken relating to examination of suspects, confiscation of goods, examination of witnesses, and inspection of scene; and make a task implementation report to be submitted to the District Head through the Head of Work Unit.

The results of interview conducted with the Head of Investigation Section of Kuningan District Civil Service Police Unit revealed that the appointment of Regional PPNS in Kuningan District Civil Service Police Unit is based on the authority of the Minister of Law and Human Rights over the Head District's proposal. A Civil Servant (PNS) proposed to be appointed as Regional PPNS has met the criteria set in Regional Regulation No. 6 of 2005 concerning Regional PPNS. Further, in terms of mutation, Regional PPNS in Kuningan District Civil Service Police Unit is rarely transferred except for the leadership element. Meanwhile, the termination of Regional PPNS generally occurs due to retirement. ${ }^{11}$

Regarding the oath/promise and inauguration of Regional PPNS in Kuningan District Civil Service Police Unit, the Head of Investigation Section of Kuningan District Civil Service Police Unit explained that the oath/promise and inauguration of Regional PPNS are carried out twice, in West Java Police Headquarters and in Kuningan District. The implementation of pronouncing oath/promise and inauguration of Regional PPNS by Kuningan District Head has been in accordance with Regional Regulation No. 6 of 2005. After the inauguration process, the Regional PPNS is given an identification card signed by Kuningan Head District and is valid for five years. ${ }^{12}$ Further, the investigations carried out by Regional PPNS in Kuningan District Civil Service Police Unit are always equipped with an investigation warrant signed by the Regional PPNS supervisor, namely Chief of Kuningan District Civil Service Police Unit.

Further, the results of interview conducted with the Head of Investigation Section of Kuningan District Civil Service Police Unit also revealed that coaching carried out toward Civil Servant Investigator includes general, technical, and operational coaching. General coaching is in the form of providing guideline, training, and supervising relating to the empowerment of Regional PPNS. Technical coaching is the responsibility of the Minister of Law and Human Rights, the Chief of the Indonesian National Police and the Attorney General in accordance with their duties and functions. Meanwhile, operational coaching is in the form of operational guidelines for Regional PPNS. Thus, general coaching is the responsibility of the Minister of Home Affairs, technical coaching is the responsibility of the Minister of Law and Human Rights, the Chief of the Indonesian National Police, and the Attorney General, and operational coaching is carried out by the District Head through the Regional PPNS Advisory Team. In this case, the financing of the implementation of general and technical coaching come from APBN, while operational coaching is funded by APBD. ${ }^{13}$

\footnotetext{
11 Ibid.

12 Ibid.

13 Ibid.
} 
Based on law enforcement theory, it is explained that law enforcement is a process which is initially the application of directors involved in making decisions that are not strictly governed by the rule of law but has element of personal judgment. Conceptually, the essence and meaning of law enforcement lies in the activity of harmonizing the relationships of values outlined in solid principles and attitude as a series of interpretation of the final stage values to create, realize, and maintain social order. ${ }^{14}$

Law enforcement does not merely mean the implementation of legislations although in reality, there is such tendency. In addition, there is another tendency to interpret law enforcement as the implementation of judges' decisions. Yet, such ideas have a weakness if the implementation of the law or the judges' decisions disturbs public peace and order. Based on the explanation, it can be concluded that the main principle of law enforcement lies in the factors influencing it. These factors have a neutral meaning so that its positive and negative impacts lie in the contents of these factors. The factors influencing law enforcement include: ${ }^{15}$

a. Factor of law.

b. Factor of law enforcement.

c. Factor of facilities/infrastructures supporting law enforcement.

d. Factor of community, namely the environment in which the law applies.

e. Factor of culture as a result of works, inventions, and tastes based on a sense of humanity.

The aforementioned factors influencing the implementation of Regional Regulation No. 6 of 2005 concerning Regional PPNS at Office of Kuningan District Civil Service Police Unit are described below:

a. Factor of law - Regional Regulation No. 6 of 2005 concerning Regional PPNS and Kuningan District Regulations No. 44 of 2016 concerning Position, Organizational Structure, Main Tasks, Functions as well as Descriptions of Duties and Work Procedures of Kuningan District Civil Service Police Unit.

b. Factor of law enforcement - the presence of Civil Servant Investigator (PPNS) in Kuningan District Civil Service Police Unit.

c. Factor of facilities/infrastructures - in the form of operational vehicles and building at Office of Kuningan District Civil Service Police Unit.

d. Factor of community - the existence of community legal awareness towards violations of regional regulations expressed in the form of reports submitted to Kuningan District Civil Service Police Unit.

e. Factor of culture - community traditions that support the enforcement of regional regulations, such as there are still many people who have a disciplined life culture.

Based on the theory concerning factors influencing law enforcement, it can be concluded that the implementation of Regional Regulation No. 6 of 2005 concerning Regional PPNS in Kuningan District Civil Service Police Unit is in line with this theory as there are factors of law, law enforcement, facilities/infrastructure, community, and culture that support the implementation of regional regulations.

\section{CONCLUSION}

Based on the analysis on the implementation of Regional Regulation No. 6 of 2005 concerning Regional Civil Servant Investigator at Office of Kuningan District Civil Service Police Unit, it can be concluded that: The regulation of Civil Servant Investigator (PPNS) based on Regional Regulation No. 6 of 2005 is that Regional Civil Servant Investigator has the duties of conducting investigation on violations of Regional Regulations in which each Regional Civil Servant Investigator must be equipped

4 Soerjono Soekanto, Loc.Cit.

15 Suwari Akhmaddhian, Penegakan Hukum Lingkungan Dan Pengaruhnya Terhadap Pertumbuhan Ekonomi Di Indonesia (Studi Kebakaran Hutan Tahun 2015). Jurnal Unifikasi, ISSN 2354-5976 Vol. 03 Nomor 01 Januari 2016.1-35.. 
with an investigation warrant signed by the supervisor of the Regional Civil Servant Investigator in carrying out its investigative duties. Besides, Regional Civil Servant Investigator also has the duties of providing coaching which includes general, technical, and operational coaching. General coaching is the responsibility of the Minister of Home Affairs which is done in the form of providing guideline, training, and supervising relating to the empowerment of Regional PPNS. Technical coaching is the responsibility of the Minister of Law and Human Rights, the Chief of the Indonesian National Police and the Attorney General in accordance with their duties and functions. Meanwhile, operational coaching is carried out by the District Head in cooperation with relevant agencies in the form of operational guidelines for Regional PPNS. District Head Regulation on the implementation of Regional Regulation No. 6 of 2005 is valid for 6 (six) months from the date of issuance.

In general, the implementation of Regional Regulation No. 6 of 2005 concerning Regional PPNS at Office of Kuningan District Civil Service Police Unit has been carried out well. This is due to the fact that the Office of Kuningan District Civil Service Police Unit has implemented District Head Regulation No. 44 of 2016 concerning Position, Organizational Structure, Main Tasks, Functions as well as Descriptions of Duties and Work Procedures of Kuningan District Civil Service Police Unit in terms of conducting investigation and inspection towards illegal buildings, places of business and business activities; conducting investigation and inspection towards community, apparatus or legal entities violating regional regulations, head district regulations, and head district decisions; and preparing material to be submitted to the National Police regarding follow up actions towards community, apparatus or legal entities violating regional regulations, head district regulations, and head district decisions. This is in line with Soerjono Soekanto who states there are some factors influencing law enforcement, including factors of law, law enforcement, facilities/infrastructure, community, and culture that support the implementation of regional regulations.

\section{SUGGESTION}

Based on the results of the analysis on the implementation of Regional Regulation No. 6 of 2005 concerning Regional Civil Servant Investigator at Office of Kuningan District Civil Service Police Unit, the following suggestions are proposed: To support its duties in realizing public order and peace in Kuningan District, it is recommended that the number of Regional PPNS personnel in Kuningan District Civil Service Police Unit is increased. In addition, to improve the performance of Regional PPNS at Kuningan District Civil Service Police Unit, the increased welfare of Regional PPNS members is needed both in terms of incentives and work equipment. The socialization of regional regulations concerning legal sanctions shall be held more intensively and continuously by Kuningan District Government so that the community is more aware of the law in order to minimize violations of regional regulations.

\section{Books and Journals}

\section{REFERENCES}

Hanif Nurcholis, Teori dan Praktik Pemerintahan dan Otonomi Daerah, Grasindo, Jakarta, 2007.

Haris Budiman dan Suwari Akhmaddhian, "Implementasi Reformasi Birokrasi Bidang Perizinan Pananaman Modal di Kabupaten Kuningan" Jurnal Unifikasi, ISSN 2354-5976 Vol. 1 No. 1 Oktober 2013.1-19.

Intan A. Ramadini, Kinerja Penyidik Pegawai Negeri Sipil (PPNS) Kota Tangerang, Skripsi, FISIP Universitas Sultan Ageng Tirtayasa Serang, 2015.

Ridwan H. R., Hukum Administrasi Negara, UII Press, Yogyakarta, 2012.

Rocky Marbun dkk, Kamus Hukum Lengkap: Mencakup Istilah Hukum dan Perundang-Undangan Terbaru, Visimedia, Jakarta, 2012. 
Soerjono Soekanto, Faktor-faktor yang Mempengaruhi Penegakan Hukum, PT. Raja Grafindo Persada, Jakarta, 2012.

Suwari Akhmaddhian, Penegakan Hukum Lingkungan Dan Pengaruhnya Terhadap Pertumbuhan Ekonomi Di Indonesia (Studi Kebakaran Hutan Tahun 2015). Jurnal Unifikasi, ISSN 2354-5976 Vol. 03 Nomor 01 Januari 2016.1-35.

Widodo Ekatjahjana, Pembentukan Peraturan Perundang-Undangan Dasar-Dasar dan Teknik Penyusunannya, Citra Aditya Bakti, Bandung, 2008.

\section{Legislations}

Undang-Undang Dasar Negara Republik Indonesia Tahun 1945.

Undang-Undang Republik Indonesia Nomor 8 Tahun 1981 tentang Hukum Acara Pidana (KUHAP).

Undang-Undang Republik Indonesia Nomor 43 Tahun 1999 tentang Pokok-pokok Kepegawaian.

Undang-Undang Republik Indonesia Nomor 9 Tahun 2015 tentang Pemerintah Daerah.

Peraturan Pemerintah Republik Indonesia Nomor 6 Tahun 2010 tentang Satuan Polisi Pamong Praja.

Peraturan Daerah Nomor 6 Tahun 2005 tentang Penyidik Pegawai Negeri Sipil Daerah.

Peraturan Bupati Kuningan Nomor 44 Tahun 2016 tentang Kedudukan, Susunan Organisasi, Tugas Pokok, Fungsi dan Uraian Tugas serta Tata Kerja Satuan Polisi Pamong Praja Kabupaten Kuningan. 